\title{
The Use of Collaborative Learning to Develop Students' Guided Writing and Oral Performance in Poetry
}

\section{Rebecca Kamala Irathaia Dass \& Azlina Abdul Aziz}

To Link this Article: http://dx.doi.org/10.6007/IJARBSS/v11-i2/8438

DOI:10.6007/IJARBSS/v11-i2/8438

Received: 13 December 2020, Revised: 10 January 2021, Accepted: 22 January 2021

Published Online: 02 February 2021

In-Text Citation: (Dass \& Abdul Aziz, 2021)

To Cite this Article: Dass, R. K. I., \& Abdul Aziz, A. (2021). The Use of Collaborative Learning to Develop Students' Guided Writing and Oral Performance in Poetry. International Journal of Academic Research in Business and Social Sciences, 11(2), 91-108.

\section{Copyright: (c) 2021 The Author(s)}

Published by Human Resource Management Academic Research Society (www.hrmars.com) This article is published under the Creative Commons Attribution (CC BY 4.0) license. Anyone may reproduce, distribute, translate and create derivative works of this article (for both commercial and non-commercial purposes), subject to full attribution to the original publication and authors. The full terms of this license may be seen at: http://creativecommons.org/licences/by/4.0/legalcode

Vol. 11, No. 2, 2021, Pg. 91 - 108

Full Terms \& Conditions of access and use can be found at http://hrmars.com/index.php/pages/detail/publication-ethics 


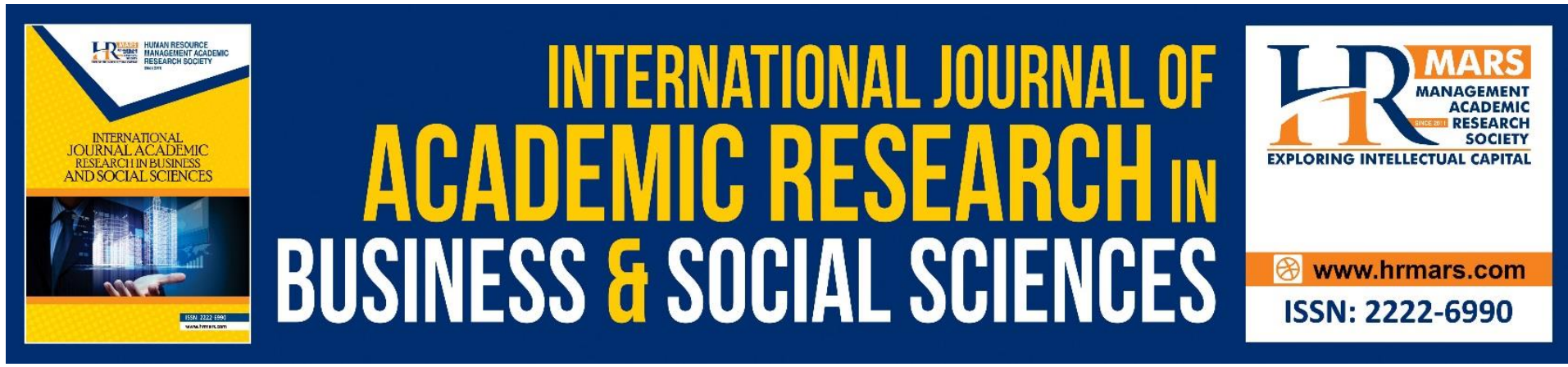

\title{
The Use of Collaborative Learning to Develop Students' Guided Writing and Oral Performance in Poetry
}

\author{
Rebecca Kamala Irathaia Dass \& Azlina Abdul Aziz \\ Faculty of Education, Universiti Kebangsaan Malaysia \\ Email: rebecca6830@gmail.com, azlina1@ukm.edu.my
}

\begin{abstract}
The ultimate purpose of collaborative learning is to help pupils develop their learning skills by cooperating with their peers. Integrating them into creative writings like poetry has been proved to facilitate their writing and oral speaking skills. This research aims to evaluate the effectiveness of collaborative learning in developing guided writing skills and oral performance in poetry for primary school students in Malaysia. The study was carried out through a quantitative approach by conducting pre- and post-assessment on thirty-six (36) Year 5 students at a school in Selangor. The results show that respondents' scores on reading and oral skills have improved after the intervention. The results of the survey on respondents' acceptability indicated that respondents had positive perceptions of the intervention. Results showed that collaborative learning helps students in developing better writing and oral skills thus developing their confidence and language skills in an environment that acquires creative learning. The limitations of past related studies and future directions for research and practice were further discussed.
\end{abstract}

Keywords: Collaborative Learning, Guided Writing, Oral Performance, Poetry, Language Arts

\section{Introduction}

English is known as the global language and accepted as one of the world's major lingua franca. It is also the firm base of one's thinking and experience on where the remaining academic knowledge is built (San Miguel et al., 2006). Thus, people need to have a good understanding and the ability to speak the language well. Being fluent and proficient in the English language among our students in Malaysia has been emphasized by the Ministry of Education Malaysia(MOE). As stated in the Malaysia Education Blueprint (2013-2025), one of the six key qualities outlined as needed by every Malaysian student to be globally competent is to be well-spoken in English as it is the lingua franca of the world. Students' who have good English proficiency are more likely to perform better academically in higher level educational institutions (Pardeep, 2014). Proficiency in English gives the student the confidence to interact freely with their language teachers and create a conducive learning environment. 
According to the National Education Blueprint (2013-2025), which was officiated by the then Prime Minister, Datuk Seri Najib Tun Razak, one of the main objectives of the blueprint was to provide a well-planned strategy for a quick and sustainable education system until 2025. The eleven shifts would need to occur to provide the changes in outcomes to be seen by all Malaysians. The second shift particularly focuses on making sure that every child is capable in both Bahasa Malaysia and English Language (National Education Blueprint 2012, E10). This move to boost the English Language was to enlarge the LINUS program, which includes literacy, teach extra skills to English teachers, and make sure students have a compulsory pass in the English language SPM paper and widening the opportunities that allow for greater influence of the language.

Literature is seen as a shift in the Blueprints where it is accepted as an instrument and resource to promote English. Therefore, it is important for teachers to always look for better learning approaches and use more effective learning materials to encourage students to be more participative during the learning process while improving their English proficiency. This can be done by incorporating poetry in the teaching lesson plans. The use of poetry in teaching English can be a creative strategy to expose students to quality yet short, fun and non-threatening pieces of literature while improving their ability to master the language.

For example, Deswita (2014) and Wahyuni (2014), had proven that the use of poetry as authentic material was effective in minimising students' difficulties in writing descriptive text and enriching their vocabularies. Adam and Babiker (2015) revealed that through teaching of English literature can intensify students' creative writing, help them develop creative imagination and language use when writing, and improve their figures of speech, literature techniques and literature elements in creative writing. In addition, since poetries are usually a short text and the patterns rhyming in poetry provide good qualities which is helpful in predicting words and phrase, they can be an amazing tool for developing students' oral skills. It is also an excellent and encouraging way of supporting students in learning of new language. Furthermore, a mixture of poetry multi-culturally shows the wide knowledge and backgrounds of English language learners.

Another advantage of using poetry in English teaching is that it is an activity that benefits in ways such as; to improvise students' oral reading fluency (Newsome, 2008), reading comprehension (Newsome, 2008), expressive reading and skills involving word recognition (Kuhn, 2005); to increase students' attitudes towards English learning (Newsome, 2008). Other than that, poetry promotes students' self-awareness and language appreciation, gives them pleasure and enjoyment in the learning process, encourages them to explore ideas and helps them identify their emotions, fears, hopes and imagination. Some challenges faced by most teachers in using poetry in teaching English are: difficult to get students interested in poetry learning and inadequate knowledge and comprehension about metaphorical words used in poetry (Marimutu, 2007). In addition, the background and culture of certain poetries are peculiar to students when they are set in the background other than Malaysia. As such, it is challenging for most students to relate and understand the literature materials.

Although there is a few research that has been carried out with regards to the benefits of poetry in English teaching, not much has been done to find out the success of the use of poetry learning on students' oral and writing fluency as well as their attitudes towards learning the language, especially in the context of Malaysian primary schools. Therefore, this study was carried out to analyse the success of the use of poetry and collaborative poetry learning in enhancing English language acquisition among primary school students in Malaysia in terms of their oral performance, writing skills, and attitude in language learning. 


\section{Research Objectives and Research Questions}

The main objective of this study was carried out as an effort to evaluate the effectiveness of the use of collaborative learning approach in developing poetry guided writing skills and oral performance of primary school students in Malaysia so that further intervention development and research in this area can be conducted. Specifically, the research objectives are:

RO1: To analyze the effectiveness of the use of collaborative learning in improving students' guided writing skills of poetry.

RO2: To analyze the effectiveness of the use of collaborative learning in improving students' oral performance skills of poetry.

This study is also conducted to answer two research questions,

RQ1: How does the use of collaborative learning help to develop students' guided writing of poetry?

RQ2: How does the use of collaborative learning help to develop students' oral performance of poetry?

\section{Literature Review \\ Definitions of Collaborative Learning}

Collaborative learning is a state or condition in which two or more people acquire or do something jointly (Dillenbourg, 1999). The "two or more" could be defined as a pair, a small group (i.e. 3-5 people), a class (i.e. 20-30 people), a community (usually involving a few hundreds or thousands of people), or a society (involves thousands or millions of people) performing learning activities to accomplish common learning purpose. As such, collaborative learning is rooted on the model that information can be established in a population in which their members socialise with each other and embark on roles that are asymmetric (Mitnik et al., 2009).

In other words, collaborative learning is referred to as methods and situations where learners participate in a mutual assignment where they lean on and are responsible to each other. According to Chandra (2015), collaborative learning happens either in 'peer-to-peer' or in bigger groups. Peer learning and instruction are defined as learning involving students as pairs or in a small group to talk about concepts or find an answer to a question/ problems. This happens in a classroom session after they are given an introduction to the materials of the course done with reading or media session before and throughout the class lesson.

In collaborative learning, students acquire to cooperate with all groups of people. Other than that, this learning approach is also useful for students who lack social skills. As they work together with other people as a team, they can boost their confidence by participating more actively in the discussion. In addition, as mentioned by Chandra (2016), since it happens that students share opinions and facts in smaller groups, students would embrace more personal opinions on their responses. This exchange of information is usually impossible in a big group setting, in which only one or two students share their ideas and the remaining of their peers merely are listeners.

In a study conducted by Pattanpichet (2011), on how collaborative learning effect was on students' English speaking achievement, the results indicated positive outcomes both in how the students showed an enhancement on their English oral performance and their feelings in the usage of collaborative learning as the strategy of instruction in a classroom with English as the medium of instruction. Working together helps students by collaborating and having a sense of unity amongst them. It also helps by making the task more approachable together. This takes away the fear that the student may have towards the 
assignment given. Teachers have better class control and manage more efficiently as the students can now cooperate in pairs or in groups. It will, in return, produce a knowledge sharing atmosphere.

Collaborative activities also encourage students to be more supportive of each other in the learning process, thus promoting their circle of social support (Tinto \& Pusser, 2006). It also helps the student manage their learning better by having peers that they can rely on (McCabe, 2003 in Wilmer 2008) as they usually feel comfortable discussing with their peers. In addition, when the learning process is done in fun yet educational way, students will learn better (Khairiyah \& Mimi 2003; Seng 2006), which will lead to improved results. In other words, collaborative learning in English classrooms can have a profound effect on students' academic achievement, cognitive development and a better attitude towards the language.

\section{Poetry Learning}

The word 'poetry' is originated from a Greek word "to make" which refers to specially made objects in words to say something about ideas, feelings, places, people and events. According to Finch (2003), though different language educators concur that poetry encourages language acquisition, they will also mention that concepts of poetic elements and cultural acceptance are usually difficult for EFL learners to comprehend. However, Utami (2012) added that EFL learners should not worry about understanding poetry, as some can be enjoyed and understood on the first impression.

Previous studies have shown that various approaches can be taken by teachers to conduct poetry learning in English classrooms. Straw et al. (1993) claimed that there are two fairly predictable patterns of dealing with poetry in literature. First is by using an expanded Directed Reading Activity or Directed Reading/Thinking Activity format. This includes introducing a poem to students and then conducting some exercises to predict about the poem. The poem reading session can be conducted either silently or aloud by the teacher. Poem can also be done in a group (either chorally or individually by students) and teacher could ask comprehension questions related to the poem.

Another approach is by using collaborative learning. For example, through dialogue with their peers, groups of students are asked to make sense of a series of poems. This has also been emphasised by Ferris (2003), where there is increased use of peer collaboration in L2 writing classrooms is supported by feedback, revision and audience. This works well with the method, which is traditionally the teacher written feedback. Peer collaboration would work well with cycles of writing, multiple drafting, and vast revision move through the dealing of product to a process in writing pedagogy and is good which is the main feature in the way of writing (Hyland \& Hyland, 2006).

Finch (2003) presented several methods to conduct poetry learning in English classrooms. One of them is by using picture poems. Picture poems offer a visual look of how words are arranged and is an effective way of encouraging students to work with the vocabulary targeted. As such, students can feel success immediately in terms of expressing themselves in English (improved self-esteem), and stress or anxiety can be decreased (reduction of affective filters). These poems will further encourage students to combine and try them out with the target language in a safe learning environment and can be displayed on the classroom walls while providing accreditation of the students' efforts and abilities. 


\section{Poetry Writing}

Poetry writing is even more difficult for non-native English speakers. Among main issues commonly encountered are incomplete sentences, poor grammar, attempting to be pretentious with their writing, lack of understanding of imagery use, and poor vocabulary and word usage (University of Richmond Writing Centre). Kidder (2019), listed eight fundamentals for poetry writing which are: poem forms/structure, imagery, sound, meaning, goals, originality (avoid cliché), minimalistic and refine poem to perfection. She also mentioned that writing poetry can benefit from strengthening students' skills in writing solid imagery, understand how to compose impactful writing and connect with their emotions.

Collins (2020), suggested that to write good poetry, students should read much poetry to familiarise themselves with poems' structure and forms. Listening to poetry can help them to understand the concept of sounds and rhyme in poems. He also suggested beginners to start small with short poems like haiku, which is easier and faster to compose. Also, poems such as shape poems and patterns poems are relatively easy to be written in a simple language. A thesaurus or dictionary can be used as a tool to enrich the word usage. Literary devices such as metaphor, imagery and allegory can also be used to enhance the poetic form.

\section{Oral Performance}

Among the problems commonly faced by students in poetry recitation (or reading out loud) are incorrect pronunciation, negative attitude towards English literature, lack of teachers' feedback on mispronounced or misread words and lack of understanding of phonetic sounds. According to Picpican-Bell (2005), teachers must comprehend their students' diverse cultural backgrounds and learning goals to address these problems. This is to provide them with suitable motivation and why they need to improve their oral fluency. By having good fluency when reading poems aloud, students will gain more confidence in speaking in English.

For example, Hedge (2000) claimed that collaborative learning helps students expand their communication abilities. This will improve their oral communication skills. According to Hughes et al. (2007), the meaning of sound is accredited to the reading and performing of poetry purpose through oral language development. When the poem is read aloud with sounds of the word, the students acquire a better comprehension and the meaning of the writing activity. It provides space for students in feeling and playing with the words of the poem. In addition, Wang (2017) cited that collaborative learning is found to be correlated with oral skills in three aspects, including students' scores the oral test, oral production and the quality of English spoken. These will, in turn, help pupils in their oral performance in poetry.

\section{Methodology}

This study was conducted by using quantitative approach through pre-post assessment before and after the collaborative learning intervention to evaluate the performance of Year 5 students at School A in district Cheras, Selangor in poetry writing and oral skills. The prepost assessment was carried out based on the poetry writing rubric which provided a measure of quality of writing skills on the basis of five criteria: poetic techniques, word usage, language conventions, effort and illustration (Lewy 2001), and also the poetry oral presentation rubric which provided a measure of quality of oral performance on the basis of six criteria: projection, articulation, pacing, expression, posture and eye contact (ESLPrintable.com).

Other than that, this study also employed perception survey by using selfadministered questionnaire to collect data on the students' perceptions of collaborative 
learning. The survey method was chosen because of the efficiency of data collection and also due to the unique characteristics of the study population, which was focused on the Year 5 students. However, the survey method might present some disadvantage since the answer choices provided might not be an accurate reflection of how the respondents truly feel.

The teacher assesed the students' poetry writing skills and oral performance before conducting collaborative poetry learning (pre-assessment). The collaborative learning intervention was then conducted for 2 weeks in August. After the intervention, the teacher was asked to reassess the students' poetry writing skills and oral performance (post assessment) and distribute the perception survey forms to the students where they were required to fill in the form and submit it back to the teacher. Data collected from both prepost assessment and survey were then analyzed using Statistical Package for Social Science (SPSS v26.0).

\section{Research sample}

The population of the study was all Year 5 students at School A in Cheras, Selangor. According to the Unit of Students Affair, the total number of Year 5 students in year 2020 was 100 students from three classes. The sample comprised of 36 students who were selected from Class B of School A by using purposive homogeneous sampling technique to participate in this study. The reason for choosing this technique was because this study was focused on particular characteristics of the population, i.e. the poetry writing and oral skills of Year 5 students after undertaking collaborative learning, and the sample shared the same characteristics of the population of interest.

\section{Research Instrument}

The research instruments used in this study were Poetry Writing Rubric, Poetry Oral Presentation Rubric and Perception Survey.

\section{Poetry Writing Rubric}

The Poetry Writing Rubric was used to assess the quality of the students' poetry writing before and after the collaborative learning intervention. The rubric was adapted from Lewy (2001) and had five evaluation criteria: Poetic Techniques, Word Usage, Language Conventions, Effort and Illustration.

Poetic Techniques measure the effectiveness of the students in using poetic techniques to reinforce the theme in their poems. Word Usage evaluates the student's use of vocabulary in their poems, in terms of word precision, clarity and ability to paint a strong, clear and complete picture in the readers' mind. Language Conventions (Spelling, Grammar and Punctuation) evaluates the appropriateness of the spelling, grammar, and punctuation in the students' poetry. Effort evaluates the extent to which the students demonstrate complete understanding of the assignment given by the teacher. Finally, Illustration evaluates the students' creativity in using illustration to enhance the meaning of their poems.

The score for each criterion was given by the teacher based on four level of proficiency: (1) beginning; (2) developing; (3) accomplished; and (4) exemplary. The total score for this rubric was 20 .

\section{Poetry Oral Presentation Rubric}

The Poetry Oral Presentation Rubric was used to assess the quality of the students' oral presentation skills before and after the collaborative learning intervention. The rubric was 
adapted from ESLPrintable.com and had six evaluation criteria: Projection, Articulation, Pacing, Expression, Posture and Eye Contact.

Projection evaluates the loudness of the students' voice when reciting their poems. Articulation evaluates the clarity of the uttered words during the poetry presentation. Pacing evaluates how fast/slow the students recite their poems. Expressions evaluates how energetic and lively were the students when reciting their poems. Posture evaluates the students' body position when presenting their poems. Finally, Eye Contact evaluates how often students made contact with their audience.

The score for each criterion was given by the teacher based on four level of proficiency: (1) no, not yet; (2) yes, sometimes; (3) mostly; and (4) always. The total score for this rubric was 24 .

\section{Perception Survey}

A perception survey to evaluate the students' perception towards collaborative poetry learning was carried out. The survey consisted of 10 items which were adapted from Pattanpichet (2011) using a four-rating scale: (1) strongly disagree; (2) disagree; (3) agree; and (4) strongly agree.

\section{Data Collection Procedure}

\section{Pre Assessment}

Thus, the teacher conducted poetry learning using traditional teacher-led approach for two weeks. At the end of the lesson, the students were asked to read aloud any English poem and compose their own poem for pre assessment. The data from the pre assessment were then collected by the researcher to proceed with data analysis.

\section{Post Assessment}

After carrying out the pre assessment, the teacher conducted poetry learning by adopting collaborative approach for another two weeks. During this period, the students were grouped in pairs to learn about three poems provided by the researcher titled 'I Am Poem' by Jennifer

L. Betts, 'That's Life' by Danny Joyce and 'Just Like' by Katherine Ayala.

In this intervention, the teacher served as a moderator while the students engaged in activities focusing on learning the poems. During the lesson, the students were instructed using a step by step procedure. During the presentation, the teacher conducted post assessment of the oral skills for each student and filled in Poetry Oral Presentation Rubric. The teacher also collected all the composed poems and conducted post assessment of the writing skills for each student and filled in Poetry Writing Rubric. The data from the post assessment were then collected by the researcher to proceed with data analysis.

\section{Perception Survey}

After completing the collaborative poetry learning session, the perception survey forms were distributed to the students where they were required to answer all items in the survey and submit it back to the teacher. The data from the survey were then collected by the researcher to proceed with data analysis. 


\section{Data Analysis Procedure \\ Descriptive Analysis}

First, Descriptive Analysis (Frequency) was carried out to analyze the demographic profile of the respondents. Next, Descriptive Analysis (Mean) was carried out to evaluate the respondents' perception of collaborative learning based on the data collected from the perception survey. The same analysis was also done to determine the change of score between pre and post assessment for both poetry writing and oral skills. The change of score indicates the change of performance in the skills.

\section{Correlation Analysis}

Correlation analysis was carried out to determine the degree of association of 'collaborative learning - writing skills' and 'collaborative learning - oral performance' skills by using simple bivariate correlation. The value Pearson coefficient was used to determine the correlation between the two variables and to determine the linearity of the relationship, i.e. to test Hypothesis $\mathrm{H} 1$ and $\mathrm{H} 2$.

\section{Data Findings}

\section{Demographic Data}

This summary of the respondents' profile is shown in Table 4.0 as follows:

Table 4.0: Demographic Profile of Respondents

\begin{tabular}{llll}
\hline Demographic & Attribute & Frequency (n) & Percentage (\%) \\
\hline Gender & Male & 18 & 50.0 \\
& Female & 18 & 50.0 \\
Class & A & 36 & 100.0 \\
& Total & $\mathbf{3 6}$ & $\mathbf{1 0 0 . 0 \%}$ \\
\hline
\end{tabular}

As shown in the table, the respondents in this study using purposive homogenous sampling consist of 18 male students and 18 female students, where all of them were from class $A$ of an urban primary school in Cheras.

\section{Descriptive Analysis}

Descriptive Analysis using Descriptive Statistics in SPSS v26.0 was conducted in this study.

\section{Poetry Writing Skills before Collaborative Intervention (PREWRITING)}

Poetry writing skills before collaborative intervention (PREWRITING) in this study refers to the students' skills in composing their own poem before the collaborative learning intervention. The assessment was made by the researcher based on five evaluation criteria: Poetic Techniques, Word Usage, Language Conventions, Effort and Illustration (Lewy, 2001) by filling in the Poetry Writing Rubric (Appendix 1). The result of descriptive statistics analysis for PREWRITING is illustrated in Table 4.1 below. 
Table 4.1: Descriptive Statistics Analysis of PREWRITING

\begin{tabular}{lcc}
\hline ITEM & Mean & SD \\
\hline PREWRITING & & \\
Poetry Techniques & 1.89 & 0.398 \\
Word Usage & 1.72 & 0.566 \\
Language & 1.67 & 0.535 \\
Effort & 2.00 & 0.414 \\
Illustrations & 2.03 & 0.560 \\
TOTAL & $\mathbf{9 . 3 1}$ & $\mathbf{1 . 5 8 2}$ \\
\hline
\end{tabular}

The results of the descriptive analysis had shown that the total score of PREWRITING for the students was fairly low for the pre assessment (mean TOTAL=9.31). This indicates that the quality of their poetry writing skills was fairly poor before the collaborative learning intervention.

\section{Poetry Writing Skills after Collaborative Intervention (POSTWRITING)}

Poetry writing skills after collaborative intervention (POSTWRITING) in this study refers to the students' skills in composing their own poem after the collaborative learning intervention. The assessment was made by the researcher based on the same five criteria in Appendix 1 Poetry Writing Rubric. The result of the analysis for POSTWRITING is illustrated in Table 4.2 below.

Table 4.2: Descriptive Statistics Analysis of POSTWRITING

\begin{tabular}{lcc}
\hline ITEM & Mean & SD \\
\hline POSTWRITING & & \\
Poetry Techniques & 2.00 & 0.478 \\
Word Usage & 2.33 & 0.478 \\
Language & 2.22 & 0.637 \\
Effort & 2.33 & 0.586 \\
Illustrations & 2.33 & 0.586 \\
TOTAL & $\mathbf{1 1 . 2 2}$ & $\mathbf{2 . 1 2 6}$ \\
\hline
\end{tabular}

The results had shown that the total score of POSTWRITING for the students was fairly high for post assessment (mean TOTAL=11.22). This indicates that the quality of their poetry writing skills has improved after undertaking the collaborative learning approach.

\section{Poetry Oral Presentation Skills after Collaborative Intervention (POSTORAL)}

Poetry oral presentation skills after collaborative intervention (POSTORAL) in this study refer to the students' ability in reading their composed poem aloud after the collaborative learning intervention The result of the descriptive statistics analysis for POSTORAL is illustrated in Table 4.3 below. 
Table 4.3: Descriptive Statistics Analysis of POSTORAL

\begin{tabular}{lcc}
\hline ITEM & Mean & SD \\
\hline POSTORAL & & \\
Projection & 2.17 & 0.609 \\
Articulation & 2.17 & 0.609 \\
Pacing & 2.28 & 0.566 \\
Expression & 2.44 & 0.504 \\
Posture & 2.44 & 0.607 \\
Eye Contact & 2.06 & 0.532 \\
TOTAL & $\mathbf{1 3 . 5 6}$ & $\mathbf{2 . 6 2 3}$ \\
\hline
\end{tabular}

The results had shown that the total score of POSTORAL for the students was fairly high (mean TOTAL=13.56). This indicates that the quality of their oral performance skills was good after going through the collaborative learning session.

\section{Perception of Collaborative Learning (CL)}

The data were contributed by the items in the Perception Survey. The result of descriptive

\begin{tabular}{|l|c|c|c|c|}
\hline ITEM & $\begin{array}{c}\text { SD \% } \\
(N)\end{array}$ & $\begin{array}{c}\text { D \% } \\
(N)\end{array}$ & $\begin{array}{c}\text { A \% } \\
(N)\end{array}$ & $\begin{array}{c}\text { SA \% } \\
(N)\end{array}$ \\
\hline \multicolumn{2}{|l|}{ PERCEPTION OF COLLABORATIVE LEARNING } & & & \\
\hline 1. Like learning poetry in pairs. & 0 & $(1)$ & $\begin{array}{c}16.7 \\
(6)\end{array}$ & $\begin{array}{c}80.6 \\
(29)\end{array}$ \\
\hline 2. Enjoy learning poetry in pairs. & & & 72.2 & 27.8 \\
& 0 & 0 & $(26)$ & $(10)$ \\
\hline 3. Feel more relaxed when learning poetry in & & 5.6 & 30.6 & 63.8 \\
pairs. & 0 & $(2)$ & $(11)$ & $(23)$ \\
\hline 4. Partner helped a lot in understanding the & & & 30.6 & 69.4 \\
poems. & 0 & 0 & $(11)$ & $(25)$ \\
\hline 5. Partner helped a lot in how to read poems & & 19.4 & 38.9 & 41.7 \\
aloud correctly. & 0 & $(7)$ & $(14)$ & $(15)$ \\
\hline 6. Partner helped a lot in poetry writing. & & 25.0 & 19.4 & 55.6 \\
& 0 & $(9)$ & $(7)$ & $(20)$ \\
\hline 7. Received constructive feedback from partner & & 13.8 & 55.6 & 30.6 \\
& 0 & $(5)$ & $(20)$ & $(11)$ \\
\hline 8. Working in pairs helped a lot in understanding & & 8.3 & 25.0 & 66.7 \\
the meaning of the poems. & 0 & $(3)$ & $(9)$ & $(24)$ \\
\hline 9. Working in pairs helped a lot in exchanging & & 5.6 & 33.3 & 61.1 \\
ideas about poems. & 0 & $(2)$ & $(12)$ & $(22)$ \\
\hline 10. Working in pairs helped a lot in improving & & 5.6 & 8.3 & 86.1 \\
communication skills. & 0 & $(2)$ & $(3)$ & $(31)$ \\
\hline
\end{tabular}

statistics analysis for $\mathrm{CL}$ is illustrated in the table above.

Table 4.4: Descriptive Analysis on Perception of Collaborative Learning

Strongly Disagree (SD), Disagree (D), Agree (A), Strongly Agree (SA) 
Collaborative learning helps in the communication skills when the students work in pairs as indicated by item 10 from table 4.4, 86.1\% ( $n=31)$. Most of the students also indicated that they loved learning poetry in pairs as indicated by item $1,80.6 \%(n=29)$. However, about $55.6 \%(n=20)$ responded to item 7 from table 4.4 by agreeing that they receive constructive feedback from their partners. Some disagreed to item 6, 25.0\% $(n=9)$ where they found their partner offered little help in poetry writing and item $5,19.4 \%(n=7)$ in oral performance that involves reading poems aloud correctly.

\section{Summary of Descriptive Analysis}

The results of Descriptive Analysis for PREWRITING, POSTWRITING, POSTORAL and CL are summarized in Table 4.5 below.

Table 4.5: Summary of Descriptive Statistics

\begin{tabular}{lcc}
\hline Variable & Mean & SD \\
\hline PREWRITING & 9.31 & 1.582 \\
POSTWRITING & 11.22 & 2.126 \\
POSTORAL & 13.56 & 2.623 \\
\hline
\end{tabular}

Overall, this study had shown that the students were able to develop poetry writing skills (mean POSTWRITING=11.22) and oral performance skills (mean POSTORAL=13.56) after working collaboratively with their partner in poetry learning.

\section{Correlation Analysis}

Correlation analysis was carried out in this study to determine the degree of association of CL-POSTWRITING and CL-POSTORAL by using simple bivariate correlation to analyze the influence of collaborative learning on the students' poetry writing and oral presentation skills, and also to test Hypothesis $\mathrm{H} 1$ and $\mathrm{H} 2$. The results are summarized in Table 4.6 below.

Table 4.6: Correlation Analysis of POSTORAL, POSTWRITING \& CL

\begin{tabular}{llccc}
\hline \multirow{2}{*}{ CL } & CL & POSTWRITING & POSTORAL \\
& Pearson & 1 & 0.041 & 0.092 \\
& Correlation & & & \\
& Sig. (2-tailed) & & 0.811 & 0.592 \\
POSTWRITING & $\mathrm{N}$ & 36 & 36 & 36 \\
& Pearson & 0.041 & 1 & $0.848^{* *}$ \\
& Correlation & & & \\
& Sig. (2-tailed) & 0.811 & & 0.000 \\
POSTORAL & $\mathrm{N}$ & 36 & 36 & 36 \\
& Pearson & 0.092 & $0.848^{* *}$ & 1 \\
& Correlation & & & \\
& Sig. (2-tailed) & 0.592 & 0.000 & \\
& $\mathrm{~N}$ & 36 & 36 & 36 \\
\hline
\end{tabular}

**. Correlation is significant at the 0.01 level (2-tailed).

It can be seen that POSTWRITING had no significant and linear relationship with $\mathrm{CL}$ $(r=0.041, p>0.001)$. This indicates that the students' perception of collaborative learning had no significant influence on their poetry writing skills after the intervention.

The analysis had also shown that POSTORAL had no significant and linear relationship with $C L(r=0.092, p>0.001)$. This indicates that the students' perception of collaborative learning had no significant influence on their oral performance skills after the intervention. 


\section{Discussions}

The findings from the data analysis with regards to the relationship with the study variables are also discussed in depth to answer the research questions developed for this study:

RQ1: How did collaborative learning help to develop students' poetry writing skills?

RQ2: How did collaborative learning help to develop students' oral performance skills?

\section{Collaborative Learning}

The results of the Descriptive Analysis on Perception of Collaborative Learning had shown that most of the students had very strongly agreed towards the use of a collaborative approach in poetry learning classroom. They mostly agreed that they enjoyed learning poetry in pairs, and it helped them a lot in improving their communication skills. As suggested by Ramadhanti (2017), students with increased poetry learning potentials should be allowed to collaborate with those of low potentials to expand and encourage their partner's motivation and interest in poetry learning.

Collaborative activities help improve students' understanding of poems and enhance their drive and initiative in poetry learning (Ramadhanti \& Yanda, 2018). Collaborative activities also encourage students to be more supportive of each other in the learning and communication process, thus promoting their circle of social support (Tinto \& Pusser, 2006). It also helps the student to manage their learning better by having peers that they can rely on (McCabe, 2003 in Wilmer, 2008) as they usually feel comfortable discussing with their peers.

\section{Poetry Writing Skills Prewriting}

For PREWRITING, the descriptive analysis results showed that most of the students had relatively poor poetry writing skills (i.e. a total score of 9.31 out of 20.00) before the collaborative learning intervention. Collins (2020) suggested that to write good poetry, students should read much poetry to familiarise themselves with poem forms and structure. Listening to poetry can also help them to understand the concept of sounds and rhyme in poems.

\section{Postwriting}

For POSTWRITING, the descriptive analysis results showed that most of the students had a good level of poetry writing skills (total score of 11.22 out of 20.00 ) after the collaborative learning intervention. The result is compatible with Yusuf et al. (2019) who found that students had an increase in their writing scores from the pre-test to the post-test after the use of CL for a duration of six weeks in class. In a study conducted by Aminloo (2013), students' writing skills improved significantly after collaborative learning intervention. This was a result of teamwork collaboration that helped leaners in improving their writing ability in English.

\section{Oral Performance Skills}

The descriptive analysis results showed that most of the students had good oral performance skills (total score of 13.56 out of 24.00) after the collaborative learning intervention. From the result of the post-test scores, the researcher found that the students could pronounce the words and sentence better than in the pre-test. 


\section{Collaborative Learning and Poetry Writing Skills}

Next, the focus is on the relationship between collaborative learning and poetry writing skills, thus to answer the following research question:

RQ1: How did collaborative learning help to develop students' poetry writing skills?

To determine the degree of association between collaborative learning and poetry writing skills, Analysis Correlation was carried out in this study by running the mean score data of post-writing against the mean score data of CL. Although in the previous discussion we have seen that the students' total score of post-writing had improved after the collaborative learning intervention, the correlation analysis results showed no significant and linear relationship between the two variables $(r=0.041, p>0.001)$. In other words, the students' perception of collaborative learning had no significant influence on their poetry writing skills after the intervention.

This is because of the difference in proficiency level within the pair group. In a study conducted by Aminloo (2013), students' writing skills improved significantly after collaborative learning intervention. This was attained through collaboration, where it helped learners in improving their writing ability in English. A detailed written sample collected indicated than the group that received treatment made better progression in the topic given. In other words, collaborative learning will only be efficient in producing better academic achievement if their partners have co-operative behaviour, interdependence, responsibility, and accountability towards their work (Chandra, 2015).

\section{Collaborative Learning and Oral Performance Skills}

Next, the discussion will be focusing on the relationship between collaborative learning and oral performance skills, thus to answer the following research question:

RQ2: How did collaborative learning help to develop students' oral performance skills?

To determine the degree of association between collaborative learning and oral performance skills, Analysis Correlation was carried out in this study by running the mean score data of POSTORAL against the mean score data of $\mathrm{CL}$. The purpose was to determine the extent to which the students' perception of collaborative learning influenced their oral performance skills.

Although in the previous discussion we have seen that the students' level of oral performance skills was good in general after the collaborative learning intervention, the correlation analysis results showed no significant and linear relationship between the two variables $(r=0.092, p>0.001)$. In other words, the students' perception of collaborative learning had no significant influence on their oral performance skills after the intervention. The results showed that the students' perception of collaborative learning did not always result in significant positive oral performance skills. Another reason is similar to collaborative writing where collaborative learning may not be as efficient in producing better academic achievement if their partners do not have co-operative behaviour, interdependence, take responsibility and accountability towards their work (Chandra, 2015).

\section{Conclusion}

In terms of poetry writing skills, this study had shown that students could improve the quality of their poetry writing after going through collaborative learning intervention, especially in 
Word Usage and Language. This suggests that collaborative writing helps students enrich their vocabulary and word usage and reduce spelling, grammar, and punctuation errors in their composed poems.

In terms of oral performance skills, this study showed that the students managed to demonstrate good oral performance skills after the collaborative learning intervention. They were mostly able to present their poems with the right expression, posture, pace, projection, articulation and eye contact. The findings from this study also revealed that achievement gap between male and female students and disparity between high and low achievers in oral performance skills were reduced.

The research results suggests that collaborative learning can be a useful and ideal way to be implemented in poetry learning in the context of Malaysian primary schools. Since poetry learning usually involves creative thinking skills, small-group interactions with peers has been effective in facilitating the students' abilities in responding to poetry more confidently, focusing on the meanings derived from poetry while improving their written and oral proficiency in the English language. Hence, it is suggested that during collaborative learning, students could be paired or divided into small groups, to encourage writing and communication skills through poetry learning.

This study has shown the value of collaborative learning and will be beneficial if collaborative learning is planned and managed effectively putting in the right thinking and care.This, would assist students' participation in the process of learning, fostering of relationship with their peers, improving their communicative capabilities and writing proficiency, improvement of comprehension about poems and strengthen their motivation in poetry learning (Park et al., 2015; Ramadhanti \& Yanda, 2018; Pattanpichet, 2011).

\section{Implication}

In terms of practicality, this study's outcome can be used as a guideline for English teachers in Malaysian primary schools to implement collaborative poetry learning in the classroom effectively as poetry can be considered a rather dull, boring and difficult to understand the aspect of English language. For collaborative learning to be an interesting and worthwhile experience for their students, the teacher should first organise the lesson properly by outlining the tasks that need to be completed and learning goals to be achieved.

During the session, the teacher should encourage positive attitudes in group members by allowing them to share ideas and creative thoughts and be more willing to listen to other people's opinions. The teacher should also be observant of each group member's achievement to look at the exchange of ideas and opinions carried out within the group and make sure that each member takes part during the discussion. In addition, this study had supported the Social Interdependence Theory (Johnson \& Johnson, 2009) and Social Development Theory (Vygotsky, 1978) where positive interdependence and social interaction in collaborative learning could help students to accomplish and achieve the common learning goals and ultimately in the development of the skills in poetry writing and oral performance.

\section{Future Research}

This study was limited to the collaboration and interaction of two students in pairs in developing poetry writing and oral performance skills. It would be useful toconsider the effects of collaborative poetry learning on other skills too such as poetry comprehension, poetry interpretation, listening, creative thinking and language art skills. Therefore, further research could be conducted in the future to understand how collaborative learning can be 
effective in developing these skills in the context of poetry learning in primary school. Since not many local studies considered exploring these factors, research investigating the relationship between these factors and collaborative learning might be useful to encourage adopting this learning approach in the teaching of poetry to primary school students in Malaysia. The population in this study was also limited to Year 5 primary school students of an urban School A in the district of Cheras. Hence, the findings of the study could not be generalized to the broader community of primary school students in Malaysia based on this study alone. As such, future research is recommended to use the larger population and sample size in other schools, especially in rural areas.

\section{References}

Adam, A. S., \& Babiker, Y. O. (2015)The role of literature in enhancing creative writing from teachers' perspectives. English Language and Literature Studies, 5(1), 109-118.

Aminloo, M. S. (2013). The Effect of Collaborative Writing on EFL Learners Writing Ability at Elementary Level. Journal of Language Teaching and Research, 4(4), 801-806.

Chandra, R. (2015). Collaborative Learning for Educational Achievement. International Journal of Research \& Method in Education, 5(2), 1-4.

Collins, B. (2020). Writing the poems. Retrieved from https://www.masterclass.com/classes/billy-collins-teaches-reading-and-writingpoetry/chapters/writing-the-poem

Debreli, E., \& Demirkan, S. (2015). Sources and levels of foreign language speaking anxiety of English as a foreign language university students with regard to language proficiency and gender. International Journal of English Language Education, 4(1), 49-62.

Deswita, S. (2014). Teaching Writing a Descriptive Text by Using the Bio-Poems Strategy to Junior High School Students. JELT 2, 2, Serie C. March (2014), 234-239.

Dillenbourg, P. (1999). Chapter 1 (Introduction) What do you mean by 'collaborative learning'?. Collaborative-learning: Cognitive and Computational Approaches. Vol. 1.

Ferris, D. R. (2003). Response to student writing: Implications for second language students. Routledge.

Finch, A. (2003). Using Poems to Teach English. Retrieved from https://www.researchgate.net/publication/260593143

Gardner, R. (1985). Social Psychology and Second Language Learning: The Role of Attitude and Motivation. London: Edward Arnold.

Ghodbane, T., \& El Achachi, H. H. (2019). Narrowing the Achievement Gap between EFL Students in Oral Expression through Cooperative Learning. Arab World English Journal (AWEJ), 10(2), 365-378.

Hedge. (2000). Teaching and learning in the language classroom. Oxford: University Press.

Hughes, R. W., Vachon, F., \& Jones, D. M. (2007). Disruption of short-term memory by changing and deviant sounds: Support for a duplex-mechanism account of auditory distraction. Journal of Experimental Psychology: Learning, Memory, and Cognition, 33(6), 1050.

Hyland, K., \& Hyland, F. (2006). Feedback on second language students' writing. Language teaching, 39(2), 83-101.

Johnson, D. W., \& Johnson, R. T. (2009). An Educational Psychology Success Story: Social Interdependence Theory and Cooperative Learning. Journal of Educational researcher, 38(5), 365-379. 
Kidder, H. L. (2019). How to Write a Poem: 8 Fundamentals for Writing Poetry That's Meaningful.Retrieved from https://self-publishingschool.com/how-to-write-a-poem/

Kuhn, M. R. (2005). A comparative study of small group fluency instruction. Reading Psychology, 26, 127-146.

Marimutu, S. (2007). Challenges faced by teachers in teaching poetry. Thesis submitted for the degree of Science with Honours (Teaching of English as a Second Language) in Universiti Malaysia Sarawak.

Ministry of Education Malaysia (2013). Malaysia Education Blueprint (2013-2025).

Mitnik, R., Recabarren, M., Nussbaum, M., \& Soto, A. (2009). Collaborative Robotic Instruction: A Graph Teaching Experience. Computers \& Education. 53(2), 330-342.

Newsome, K. E. (2008). Using Poetry to Improve Fluency and Comprehension in Third-Grade Students. Georgia Educational Researcher, 6(1), 1-21.

Pardeep, K. (2014). Effect of Proficiency in English Language on Academic Performance of Post Graduate Management Students of Marathwada Region (Maharashtra), India, IOSR Journal of Business and Management (IOSR-JBM), 16(5), 10-16.

Park, J. Y., Simpson, L., Bicknell, J., \& Michaels, S. (2015). When it rains a puddle is made: Fostering academic literacy in English learners through poetry and translation. English Journal, 104(4), 50-58.

Pattanpichet, F. (2011). The Effects of Using Collaborative Learning To Enhance Students English Speaking Achievement. Journal of College Teaching \& Learning, 8(11), 1-10.

Ramadhanti, D. (2017). Penerapan Model Kooperatif Tipe CIRC dalam Pembelajaran Menulis Narasi Siswa Kelas VII SMP Negeri 2 Lembah Gumanti. Gramatika, 3(1), $27-42$.

Ramadhanti, D., \& Yanda, D. P. (2018). Understanding Poetry Through The Use Of Cooperative Learning Model. STKIP PGRI Sumatera Barat.

San Miguel, J., Barraquio, D., \& Revilla R. (2006). Smart English: more than a work test for grammar and syntax, Introduction. C\&E Publishing.

Seng, T. H. (2006). Cooperative learning and achievement in english language acquisition in a literature class in a secondary school.

Straw, S. B., Craven, L., Sadowy, P., \& Baardman, P. (1993). Poetry in the Primary Classroom: Collaboration and Response. Reading Horizons: A Journal of Literacy and Language Arts, 34 (2).

Tinto, V., \& Pusser, B. (2006). Moving From Theory to Action: Building a Model of Institutional Action for Student Success. National PostSecondary Education Cooperative (NPEC).

Utami, I. L. P. (2012). Learning English through Poetry for EFL students. Bahasa dan Seni: Jurnal Bahasa, Sastra, Seni, dan Pengajarannya, 40(1).

Vygotsky, L. (1978). Mind in society: The developmental of higher psychological process. Cambridge, MA: Harvard University Press.

Wahyuni, A. (2014). The Effectiveness of Teaching Writing Descriptive Text Using Cinquain Poetry. A Thesis of BINUS University Jakarta.

Wang, W. (2017). Improving Students' Oral Skills Through A Cooperative Learning Approach To Teaching Chinese College English.

Wilmer, E. (2008). Student Support Services for the Underprepared Student. Inquiry: The Journal of the Virginia Community Colleges, 13(1), Art. 2, 5-20.

Yusuf, Q., Jusoh, Z., \& Yusuf, Y. Q. (2019). Cooperative Learning Strategies to Enhance Writing Skills among Second Language Learners. International Journal of Instruction, 12(1), 1399- 1412. 